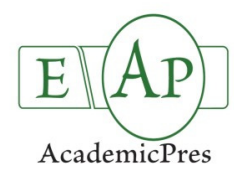

\title{
Multicriteria Analysis of the Effects of Field Burning Crop Residues
}

\author{
Vasilica STAN*, Gina FÎNTÎNERU, Mircea MIHALACHE \\ University of Agronomic Sciences and Veterinary Medicine, 59 Mărăş̧ti Bd., Sector 1, 011464, Bucharest, Romania; \\ vstan@agro-bucuresti.ro (*orrespondingauthor)
}

\begin{abstract}
Burning crop residues is frequently used by Romanian land users to clean agricultural fields after crop harvest for ease in postharvest soil tillage. Huge amounts of crop residues biomass, on very large areas, were burned in Romania in the last twenty years, as compared to other countries. There are several reasons (e.g. the lack of equipment to gather the crop residues and to transport and store them, the diminishing of the livestock after 1990, the absence of other alternatives, especially in the 1990s, but also the lack of information regarding the good practices) that are evocated to support the use of this method. However, this method is not a sustainable one since it can cause many environmental damages, especially related to soil properties (physical, chemical and biological), greenhouse gas emission and crop yields. Contrary to the above stated, crop residues' addition to the soil may restore damaged soil structure, improve aggregate stability, soil water retention, soil fertility, increase total organic carbon (TOC) and total nitrogen (TN) etc. The purpose of this paper is to make a multicriteria analyze of the effects of crop residue management on the soil, agricultural productivity and environment. At the same time, the use of crop residues biomass as a source of energy is presented as an alternative, given its potential ability to offset fossil fuels and reduce $\mathrm{CO}_{2}$ emissions.
\end{abstract}

Keywords: crop residues, soil properties, crop yields, greenhouse gases, sustainability

\section{Introduction}

Open field burning of crop residues is a simple method for land users to clean agricultural land after crop harvest to facilitate soil tillage. Crop residue burning has proved to be efficient in controlling insects, diseases, and the emergence of invasive weed species (Pintilie et al., 1985; Kutcher and Malhi, 2010; Estrellan and Iino, 2010; Gonçalves et al., 2011). But, as a general practice, its use has been questioned for several reasons, such as: economic loss (Liu et al., 2008; Kludze et al., 2013), environmental degradation (Campbell et al., 1998; Liu et al., 2008; Zang et al., 2008; Awasthi et al., 2010; Estrellan and Iino, 2010; Viana et al., 2013), adverse health impact (Viana et al., 2008; Awasthi et al., 2010; Agarwal et al., 2012) and loss of soil organic matter (Lal, 2008; Granged et al., 2011) which may contribute to the overall deterioration of agricultural soil productivity.

High soil quality equates to high productivity without significant soil or environmental degradation. Soil quality describes the status or specific condition of the soil as a result of its management (Karlen et al., 2003). Evaluation of soil quality is based on physical, chemical and biological characteristics, which vary as a function of the applied management, such as tillage, crop rotation, and the handling of crop residues (Carter, 1994). Management practices that simultaneously improve soil properties and yield are crucial to sustain high crop production and minimize detrimental impact on the environment. Crop residues are important in the maintenance and protection of soil quality (Kludze $e t$ al., 2013), and the returning crop residue associated with some other agronomic practices, such as no tillage and crop rotation may improve soil quality and productivity, and may also be useful for the environment (Malhi et al., 2006; Fuentes et al., 2009).

Concerns regarding the effects of field burning crop residues have arisen in Romania in the past twenty years. Therefore, the Romanian government, as well as researchers in the field of agronomy, the organizations fighting for environment quality and protection, and the civil society are acting against the practice of field burning crop residues that has taken place with regaining ownership of agricultural land and with the agricultural land privatization. However, in Romania, in the last twenty years, crop residues were burned on the largest areas, as compared not only, but also with European countries, even considering that before 1990 such practice was very rare and required very well-grounded scientific and economic approaches. The environmental consequences of field burning residues are not seen only in terms of air pollution, but also in terms of intake decreasing of organic matter in the soil, that is important to increase soil fertility and to improve its physical, chemical and biological properties which consequently affect the agricultural productivity.

The purpose of this paper is to analyze, from an agronomic, economic and environmental perspective, the effects of crop residues management on the soil, agricultural productivity and environment, to reveal the need to limit 
the practice of field burning residues to strict needs and to illustrate the potential of crop residues to induce sustainable changes in dynamic soil quality (Franzluebbers, 2002). Also, the use of crop residues biomass as a source of energy is presented as an alternative. This is only the first step in the scientific approach of this problem. Several projects are ready for future research in this area.

\section{Field burning crop residues: a Romanian study-case}

Burning crop residues after harvest is becoming a very common practice in Romania (Fig. 1) since 1990. There are some reasons which have always been evocated by the land users to justify the field burning crop residues: (1) the lack of equipment to gather the crop residues and to transport and store them, especially for the small and medium farmers; (2) the diminishing of the livestock after 1990 (NIS, 2013) when Romania started the transition to the market economy; (3) the lake of information regarding the good practices especially for the small farmers; (4) the lake of interest for an alternative use of crop residues, especially during the period 1990-2000 or afterwards; (5) the argument brought up by most farmers (small or big farmers) that the soil tillage practice is of good quality if the crop residues are burned before. All these reasons are not sustainable, so the land managers need to know the effect of their management on soil ecosystem functioning, in addition to the effect of environmental factors beyond their control (Franzluebbers, 2002).

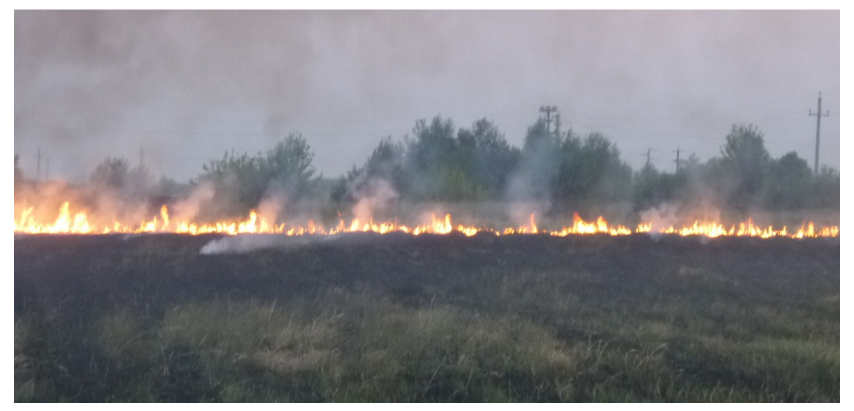

Fig. 1. Evening open field burning of crop residues in Giurgiu county, Romania. Photo source: Vasilica Stan and Françoise Picard-Bonnaud, 26th August 2013

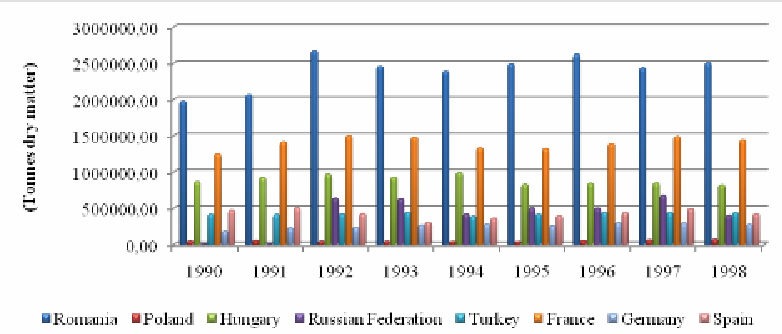

Fig. 2. a.The quantities of biomass burned in Romania compared with different European countries (1990-1998), FAO (2013), all GHG Crops + (Total)

In Fig. 2.a. and 2.b., and in Fig. 3 the annual quantities (tons of dry matter) of crop residues, according to FAO (2013), are given, which represent aggregated data that may include official, semi-official or estimated data between
1990 and 2010. Figs. 2.a. and 2b. (1990-2006), presents the situation before the accession to the European Union (EU), and Romania is compared with old European countries such as France, Germany, Spain where agriculture is well developed, with new European countries, such as Hungary or Poland, which are much closer to Romania from an economic point of view, and with non-EU countries, such as the Russian Federation and Turkey which also have a developed agriculture. In the 1990-2006 period, in Romania, large amounts of crop residues were burned (between 2 million and more than 2,5 million tons biomass dry matter) as compared to the above European countries. After 2007 and until 2010 (Fig. 3), the amount of crop residue burned in Romania still remained high in comparison to other countries, but a decrease of these quantities (below 2,0 million tons biomass dry matter) and a continuous downward trend occur, due to the new strategies and environmental policies.

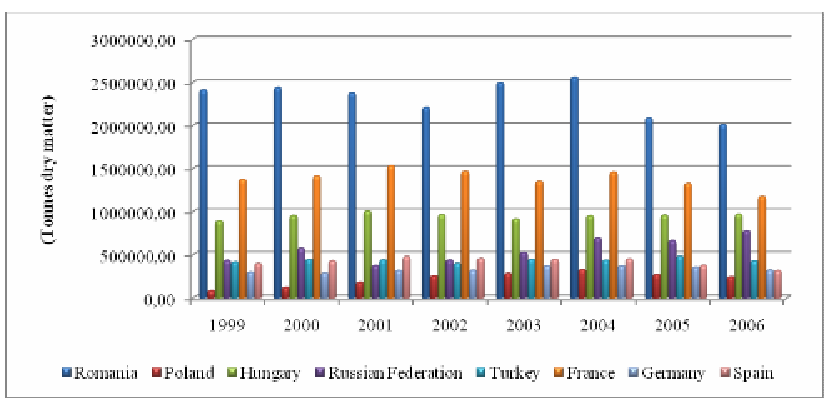

Fig. 2.b. - The quantities of biomass burned in Romania compared with different European countries (1999-2006), FAO (2013), all GHG Crops + (Total)

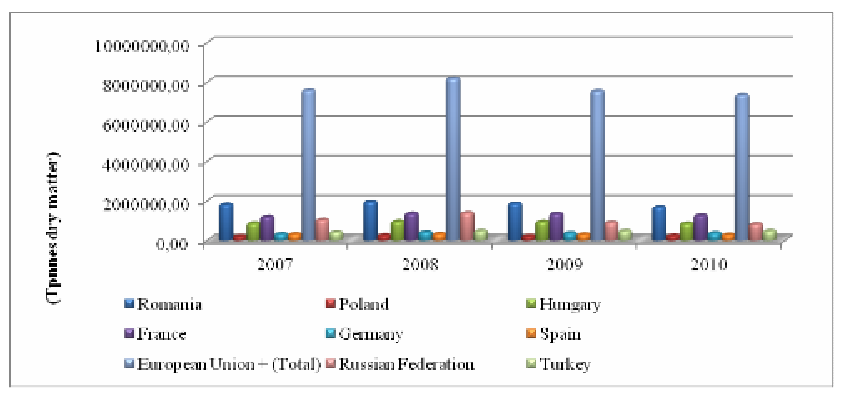

Fig. 3. The quantities of biomass burned in Romania after EU accession (2007-2010) compared with different European countries, FAO (2013), all GHG Crops + (Total)

The Soil Quality Monitoring of Romania (Tab. 1) shows that $62.24 \%$ of agricultural soils are characterized by low humus content, $21.34 \%$ by a medium content, $13.28 \%$ by either extremely-low and very low humus content and only $3.14 \%$ of soils are characterized by a high and an excessively high content. Generally, the reduced organic matter content is due to the slope processes and to the neglection of organic fertilization in the last 30-40 years, the agriculture being mostly based on chemical fertilization, and this, only at low rates. The content of humus that characterize the soil classes is presented in Tab. 2 (Canarache et al., 1987). Based on these considerations, a multicriteria analysis of the effects of field burning crop residues can be considered. 
Tab. 1. The distribution of agricultural monitoring sample plots, level I by class of soil humus content (Dumitru et al., 2000)

\begin{tabular}{cccccccccc}
\hline & No. Plots & Extremely low & Very low & Low & Medium & High & Very high & Extremely high & Excessive \\
\hline $\begin{array}{c}\text { Humus } \\
\text { content }\end{array}$ & 670 & 1.64 & 11.64 & 62.24 & 21.34 & 1.94 & 0.45 & 0.60 & 0.15 \\
\hline
\end{tabular}

Tab. 2. Classes of soil humus content (Canarache et al., 1987)

\begin{tabular}{cccc}
\hline & & Humus content for different texture classes (\%) & Clay \\
\cline { 2 - 4 } & Sand & Loamy & $\leq 1.0$ \\
\hline Extremely low & $\leq 0.2$ & $\leq 0.6$ & $1.1-2.0$ \\
Very low & $0.3-0.5$ & $0.7-1.3$ & $2.1-5.0$ \\
Low & $0.6-1.0$ & $1.4-3.0$ & $5.1-10.0$ \\
Medium & $1.1-2.0$ & $3.1-6.5$ & $10.1-16.0$ \\
High & $2.1-5.0$ & $6.6-10.5$ & $16.1-21.0$ \\
Very high & $5.1-8.7$ & $10.6-13.9$ & $21.1-35.0$ \\
Extremely high & $8.8-20.0$ & $14.0-26.5$ & $\geq 35.1$ \\
\hline Excessive & $\geq 20.1$ & $\geq 26.6$ & \\
\hline
\end{tabular}

\section{A multicriteria analysis of crop residues field burning effects}

Concerns related to intensive agriculture and its effects on the environment have led many researchers, everywhere in the world, in the last 30-40 years, to study the effects of some agricultural practices, such as field burning crop residues, on soil or in the atmosphere (Malhi et al., 2006; Singh et al., 2007; Zhang et al., 2008; Fuentes et al., 2009; Soon and Lupwayi, 2012 etc.). Therefore, a multicriteria analysis of crop residues field burning effects will refer to soil properties (physical, chemical and biological), greenhouse gas emission and crop yields. In the same time, the energetic value of crop residues will be considered a very important criterion, as this is one of the most important alternatives to field burning residues.

The effects of residue removal on soil properties and environmental quality need to be investigated more vigorously, as it is essential for these effects to be carefully weighed on a site-specific basis when making a determination about residues removal (Kludze et al., 2013).

\section{Crop residues and soil properties}

The vast majority of soil organic matter (SOM) originates from plant inputs, although this material may pass through several trophic levels prior to acquiring the characteristics of stable SOM (Johnson et al., 2007). Soil C (soil carbon) sequestration benefits refers to: soil quality improvement, the increase of soil productivity, the reduction of soil erosion and sedimentation, the decrease of eutrophication and water contamination (Lal, 2007). Therefore, the soil deprivation of $\mathrm{C}$ and $\mathrm{N}$ (soil nitrogen) with removal of straw suggests that the practice of removing straw from fields for on-farm and industrial uses in the long run may result in soil degradation (Campbell et al., 1998).

Many authors (Malhi et al., 2006; Fuentes et al., 2009; Verhulst et al., 2011; Soon and Lupwayi, 2012; Li et al., 2013) have reported the effects of crop residues when they were retained on the top soil, especially when this practice was combined with crop rotation and soil tillage (minimum tillage or no tillage/zero tillage). Moreover, incorporation of crop residues, such as straw, into the soil, builds up soil carbon $(\mathrm{C})$ as well as soil nitrogen $(\mathrm{N})$ and returns valuable nutrients to the ecosystem. Such build-up of soil C and N will not take place if the straw is removed from the soil (Nguyen et al., 2013).

Management that causes a decline in soil quality reduces its functional abilities, whereas stewardship preserves these abilities. Given the resilience of nature, appropriate soil management techniques can be expected to restore the ecosystem functions once degraded (Franzluebbers, 2002). Retaining instead of burning residues provides several potential benefits (Hartemink, 2008; Rayment, 2003) such as improving soil physical, chemical and biological properties, and reducing fertiliser requirements through recycling nutrients in the residues, sequestering $C$ etc. Successful integration of crop residue management strategies into cropping systems requires understanding of how crop residues influence cycling of nutrients from soil and fertilizers, as well as their effects on soil chemical, physical and biological properties, and crop production (Malhi et al., 2006).

Effects of organic inputs over time on soil physical properties (soil aggregate stability, soil bulk density, water retention etc.) was reported by several authors (Zhang and Peng, 2006; Singh et al., 2007; Fuentes et al., 2009; Yao et al., 2009). The organic products additions to the soil increase aggregate stability by a factor of 1.1-10.0, and this increase is related to the decomposition dynamics of the inputs (Abiven et al., 2009). Soil aggregate stability is very important to avoid soil erosion. Malhi et al. (2006) reported that during a 4-year experiment, the addition of straw increased the proportion of larger aggregates by $3 \%$ for $>38$ $\mathrm{mm}$ and by $1 \%$ for $12.7-38.0 \mathrm{~mm}$ size and decreased the proportion of wind erodible aggregates by $1 \%$ for $0.42-0.83$ $\mathrm{mm}$ and by $3 \%$ for $<0.42 \mathrm{~mm}$ size. They also noted that the effects of straw retention (SR) on soil aggregate stability were improved when straw retention was combined with no tillage (NT) practice, which resulted in a lower proportion of wind-erodible aggregates (34\%) and a higher proportion of large aggregates (37\%), whereas conventional tillage (CT) + not straw retention (NSR) combination resulted in a 
great proportion of wind-erodible aggregates (50\%) and a low proportion of large aggregates (18\%). Therefore, an appropriate management of organic matter additions to soils may increase aggregate stability and thus, reduce crusting and erosion problems (Abiven et al., 2009).

It was also shown that the increase of soil carbon content by using crop residues may restore damaged soil structure in the case of puddling in rice, and may increase the size and stability of aggregates, water retention and infiltration and decrease bulk density, dispersion ratio and soil strength (Singh et al., 2007). Moreover, the results of a tillage/crop residue management study (Sparrow et al., 2006) showed that wet aggregate stability was significantly higher with crop residues (16.2\%) than without crop residues $(13.8 \%)$ averaged across all tillage treatments.

Fuentes et al. (2009) reported that one of the benefits of retaining residues in the plots subjected to zero and conventional tillage was the reduction in both moisture spatial variability and soil mechanical resistance, but as no residues remained on the soil surface water flowed more easily and the surface was sealed because of the decreased aggregate stability. So, straw retention treatment combined with no tillage kept high soil moisture, rather than no straw retention treatment in the top soil (0-15 cm depth) as it was reported by Malhi and Lemke (2007), which is very important, especially for the arid areas.

Not only crop residues are a primary substrate for the replenishment of soil organic matter, but they also serve as an important source of plant nutrients (Lal, 1995). Crop residues have traditionally been incorporated into the soil as a source of nutrients and organic matter (Redy et al., 2001; Soon and Lupwayi, 2012). Soil organic matter is an ecosystem component with agronomic and environmental functions and is affected by soil management (Franzluebbers, 2002; Diekow et al., 2005). Crop residues are a renewable and vital organic resource for maintaining soil productivity. Intensive cropping with no return of crop residues and other organic materials results in loss of soil organic matter and that is not sustainable (Singh et al., 2007). As it was already mentioned, build-up of organic matter in soil is a slow process and it takes many years to accumulate significant amounts of organic matter in soil (Malhi et al., 2006) that are able to improve soil properties.

Crop residues, such as wheat or soybean residues, added either alone or in combination with $\mathrm{P}$ fertilizers, can improve soil $\mathrm{P}$ fertility by decreasing $\mathrm{P}$ sorption capacity and favouring a building-up in labile inorganic $P$, and moderately labile organic P (Reddy et al., 2001). There are differences between residue types regarding nutrient content. As it was reported by Li et al. (2013), soybean residues have the highest total nitrogen concentration and the lowest $\mathrm{C} / \mathrm{N}$ ratio, whereas maize residues show the opposite trend. The residue type and placement significantly affect cumulative $\mathrm{C}$ mineralization. The cumulative mineral $\mathrm{N}$ was higher in soils amended with soybean residues than in those amended with maize residues. For these reasons, crop rotation should be associated with the type of crop residues retention and no tillage, as another very important element for a sustainable soil management technique.

A significant increase of top soil organic carbon content, when crop residues were retained, was also reported by different authors: (Malhi et al., 2006, Singh et al., 2007; Cayuela et al., 2009; Fuentes et al., 2009; Thorburn et al., 2012; Navarro-Noya et al., 2013). Crop residue retention had a more pronounced effect on the soil bacterial communities when no tillage was applied. As it was reported by Navarro-Noya et al. (2013), retaining the crop residues significantly increased total organic carbon (TOC) and total $\mathrm{N}(\mathrm{TN})$ in soil, but decreased the $\mathrm{pH}$. Also, regarding the soil pH, Fuentes et al. (2009) showed that when soil was cultivated with maize and wheat, the $\mathrm{pH}$ was significantly affected by treatments, but only in the first $5 \mathrm{~cm}$ layer. In conventional tillage with residue retention $(\mathrm{CT}+\mathrm{R})$, conventional tillage without residue retention $(\mathrm{CT}-\mathrm{R})$ and zero tillage $(\mathrm{ZT})$ with residue retention $(+\mathrm{R})$ treatments, $\mathrm{pH}$ ranged from 6.0 to 6.5 .

Campbell et al. (1998) reported that 6 years of no tillage on a thin Black Chernozem in Saskatchewan, Canada, in a fallow-wheat-wheat rotation tended to reduce TOC and $\mathrm{TN}$ when straws were removed. At the end of four growing seasons, the mass of TOC and TN in the $0-15 \mathrm{~cm}$ soil depth tended to be higher, whereas light fraction organic matter (LFOM), light fraction carbon (LFC), and light fraction nitrogen (LFN) were significantly higher under straw retained (S) than under straw removed (NS) treatments. Compared to NS, the $S$ treatment increased TOC by $3 \%$, TN by $6 \%$, LFOM by $23 \%$, light fraction organic carbon (LFOC) by 37\%, and LFN by 36\% (Malhi et al., 2006). After eight crop seasons, tillage and straws management had no significant effect on TOC and total organic $\mathrm{N}$ (TON) in the top $15 \mathrm{~cm}$ of soil, but the LFOC and LFON were higher with $S$ than NS, and also higher under NT than under CT. Compared to NS, the $S$ treatment increased LFOC by $24 \%$ and LFON by $10 \%$. Increase in light fraction of organic $\mathrm{C}$ and $\mathrm{N}$ fractions due to straw retention was closely associated with greater input of $\mathrm{C}$ and $\mathrm{N}$ to soil through straw and chaff in the $S$ treatments compared to NS treatments (Malhi and Lemke, 2007). Sparrow et al. (2006) also reported that carbon (C) biomass in the 0-10 $\mathrm{cm}$ depth increased with decreasing tillage intensity. Soil microbial biomass $\mathrm{C}$ and $\mathrm{N}$ concentrations were much higher at the surface $10 \mathrm{~cm}$ than in the $10-20 \mathrm{~cm}$ depth (519 $\mathrm{mg} \mathrm{C} \mathrm{kg}^{-1}$ and $39 \mathrm{mg} \mathrm{N} \mathrm{kg}^{-1}$ in the $0-10 \mathrm{~cm}$ depth versus $229 \mathrm{mg} \mathrm{C} \mathrm{kg}^{-1}$ soil and $13 \mathrm{mg} \mathrm{N} \mathrm{kg}^{-1}$ soil in $10-20 \mathrm{~cm}$ depth). Microbial biomass C:N ratio in the $0-10 \mathrm{~cm}$ depth was also the highest in NT and the lowest in disked twice. Therefore, crop residues returned to crop lands can sustain soil organic carbon (SOC) content and improve soil fertility and biological activity (Cayuela et al., 2009).

\section{Field burning crop residues and the greenhouse gas emissions}

Generally, agricultural activities are significant producers of $\mathrm{CH}_{4}$ and $\mathrm{N}_{2} \mathrm{O}$ (IPCC, 2007). Of the three main gases that are influenced by land management and that are responsible for the potential greenhouse effect, $\mathrm{CO}_{2}$ has the greatest climate forcing potential (57\%), while $\mathrm{CH}_{4}$ and $\mathrm{N}_{2} \mathrm{O}$ account for $27 \%$ and $16 \%$, respectively (CAST, 1992). Modern agriculture contributes to the production of atmospheric greenhouse gases (GHG) with about $14 \%$ of global net $\mathrm{CO}_{2}$ emissions (IPCC, 2007).

Field burning of crop residue converts a great deal of nutrients to gaseous form, which is then lost from the site 
259

(Haider, 2013). It has been reported that field burning of crop residues represents a major source of greenhouse gase $\left(\mathrm{CO}_{2}, \mathrm{CO}, \mathrm{CH}_{4}, \mathrm{H} 2, \mathrm{CH}_{3} \mathrm{Cl}, \mathrm{NO}, \mathrm{HCN}, \mathrm{CH}_{3} \mathrm{CN}, \mathrm{COS}\right.$, etc.) and aerosols (Crutzen et al., 1979; Johnson et al., 2007; Sahai et al., 2007; Zhang et al., 2008; Vadrevu et al., 2013). In Asia, the annual contribution from open field burning of biomass is estimated to emitting $0.37 \mathrm{Tg}$ of $\mathrm{SO}_{2}, 2.8 \mathrm{Tg}$ of $\mathrm{NO}_{x}, 1100 \mathrm{Tg}$ of $\mathrm{CO}_{2}, 67 \mathrm{Tg} \mathrm{CO}$ and $3.1 \mathrm{Tg}$ methane $\left(\mathrm{CH}_{4}\right)$ (Streets et al., 2003).

There are different alternatives to field burning crop residues (e.g. soil amendment, biomass feedstock for energy production etc.). As it was already argued, sequestration of $\mathrm{C}$ from plant biomass into soil organic matter (SOM) is a key sequestration pathway in agriculture. There are multiple benefits to sequestering $\mathrm{C}$ in forest and agricultural soils, beyond the obvious benefit of offsetting $\mathrm{CO}_{2}$ emissions (Johnson et al., 2007).

\section{Crops residues and their effects on crop yields}

From an economic point of view, crop residues, such as straw, are valuable, as they may contribute to improve soil organic matter and soil properties which may result in agricultural productivity (Kludze et al., 2013). Crop residues can have significant effects on crop production, especially when their use is in association with other agricultural practices such as crop rotation, reducing the number of tillage or zero tillage. There are many ways in which crop residues may become benefic for the crop yields (e.g. soil moisture conservation, soil properties improving nutrient content etc.). In a Gray Luvisol, sandy clay loam soil and a second 4 years cycle rotation experiments, Malhy and Lemke (2007) reported that the beneficial effect of zero tillage (ZT) and straw return, on crop yield, is accomplished mainly through conservation of soil moisture in a dry year or in a dry region. Soil moisture content was higher in ZT than in conventional tillage (CT) by $1.5 \%$ in the $0-15 \mathrm{~cm}$ and by $1.9 \%$ in the $15-30 \mathrm{~cm}$ depth and also higher in retained straw $(\mathrm{R})$ than in not retained straw (NR) by $1.9 \%$ in the $0-15 \mathrm{~cm}$ and by $2.6 \%$ in the $15-30 \mathrm{~cm}$ depth. Also, zero tillage practiced for 14 years, with crop residues retained in the field, resulted in a clayey Cumulic Phaeozem soil with a better quality and, in addition, producing higher wheat and maize yields than the plots subjected to conventional tillage (Fuentes et al., 2009). Residues retention, on average, increased the wheat grain yield by 1.31 times (Bakht et al., 2009). Regarding plant growth, zero tillage with residue retention was characterized by a slower initial growth than conventional tillage practices, but this was compensated by increased crop performance in the later stages, with a crucial influence on final grain yield (Verhulst et al., 2011).

\section{Crop residues and their energetic use}

In 2010, about $62 \%$ of renewable energy in the European Union (EU) was generated from biomass (Szabó et al., 2011). Agricultural biomass continues to gain attention as a source of alternative energy, given its potential ability to offset fossil fuels and reduce $\mathrm{CO}_{2}$ emissions, while simultaneously providing an added source of income to farmers (Kludze et al., 2013). The use of biomass as raw materials for bioenergy and biochemical production is encouraged by the need for a secure energy supply, a reduction of fossil $\mathrm{CO}_{2}$ emissions and a revitalization of rural areas (Cherubini and Ulgiati, 2010).

Our strong dependence on fossil fuels results from the intensive use and consumption of petroleum derivatives which, combined with diminishing oil resources, cause environmental and political concerns (Cherubini and Ulgiati, 2010) and many problems such as energy crisis and global warming since the Industrial Revolution (Liu et al., 2008). An alternative can be represented by lignocellulosic materials. In fact, lignocellulosic feedstocks can be supplied either from dedicated crops or as residues from agricultural, forestry and wood industry (Cherubini and Ulgiati, 2010). Biomass fuels (e.g. wood waste, crop residues, energy crops), in contrast, are considered renewable and carbon neutral (Nguyen et al., 2013). This feedstock is made of three main components (cellulose, hemicellulose and lignin) which can be refined into different final products using a set of jointly applied technological processes. Among the different possible feedstocks, agricultural residues are a widespread lignocellulosic biomass source available in many countries (Cherubini and Ulgiati, 2010).

In areas where plants are cultivated on large surfaces, such as Romanian plain, there is a potential for removing straws or other crop residues for alternative uses, given the recent increasing interest for production of biofuels as a result of the EU Directive on the promotion of the use of energy from renewable sources (2009/28/EC), which sets an overall target of $20 \%$ renewable energy to be reached by 2020. In the framework of targets fixed by this directive, each member state had to adopt a National Renewable Energy Action Plan (NREAP) detailing the mandatory national targets in terms of sources and uses of renewable energy (Monforti et al., 2013). The agricultural crop residues contribution to primary energy production has to be evaluated in the NREAPs template (European Commission, 2009).

Given the concentrated crop production regions in the Romanian South Plain or the Romanian West Plain, crop residues from corn (Zea mays L.), wheat (Triticum aestivum L.), rape (Brassica rapa L.), sunflower (Hellianhus annuus L.) and soybean (Glycine max L. Merr.) are considered to be particularly promising sources of biomass feedstock to replace conventional fuel. Employment of agricultural areas for the production of biomass crops, at the expense of food crops production and the burning of huge amounts of crop residues proves to be unprofitable.

\section{Conclusions}

In Romania, large amounts of crop residues are burned in open field. However, this is not a sustainable way to remove them from agricultural fields since it may affect environment (soil properties, air quality etc.), and agricultural productivity. In this study, based on current estimates of the quantity of crop residues burned in the open field, a multicriteria analysis of the negative effects on the environment has been presented and the benefits of incorporating crop residues in agricultural soils or their use for energy, have been given as alternatives. These alternatives can contribute to the increase of the sustainability of crop residue disposal and can reduce the 
risks posed by the open field burning of crop residues.

Increasing atmospheric emissions of greenhouse gases cause the biggest concerns on the effects of burning crop residues on the environment. This burning is associated also with the impoverishment of soil organic matter and consequently, with the degradation of the physical, chemical and biological properties of soil and its fertility reduction. Therefore, carbon sequestration in soil is a key solution to limit burning crop residues in the open field. Besides, using alternatives for agricultural crops residues, such as fuel production, is able to deliver new amounts of energy, but also to support farmers for land release and protect the environment.

To better control the effects of burning crop residues, as well as for the adoption of effective solutions, an up-to-date data of crop residue field burning and special investigations are necessary. Also, both the short and long-term effects of crop residues burning on soil properties and environmental quality need to be investigated more rigorously.

\section{References}

Abiven S, Menasseri S, Chenu C (2009). The effects of organic inputs over time on soil aggregate stability-A literature analysis. Soil Biology and Biochemistry 41:1-12.

Agarwal R, Awasthi A, Singh N, Gupta PK, Mittal SK (2012). Effects of exposure to rice-crop residue burning smoke on pulmonary functions and Oxygen Saturation level of human beings in Patiala (India). Science of the Total Environment 429:161-166.

Awasthi A, Singh N, Mittal S, Gupta PK, Agarwal R (2010). Effects of agriculture crop residue burning on children and young on PFTs in North West India. Science of the Total Environment 408:4440-4445.

Bakht J, Shafi M, Jan MT, Shah Z (2009). Influence of crop residue management, cropping system and $\mathrm{N}$ fertilizer on soil $\mathrm{N}$ and $\mathrm{C}$ dynamics and sustainable wheat (Triticum aestivum L.) production. Soil and Tillage Research 104:233-240.

Cayuela L, Sinicco T, Mondini C (2009). Mineralization dynamics and biochemical properties during initial decomposition of plant and animal residues in soil. In: Li LJ, Han X-Z, You M-Y, Yuan Y-R, Ding X-L, Qiao Y-F (2013). Carbon and nitrogen mineralization patterns of two contrasting crop residues in a Mollisol: Effects of residue type and placement in soils. European Journal of Soil Biology 54:16.

Campbell CA, Selles F, Lafond GP, McConkey BG, Hahn D (1998). Effect of crop management on $C$ and $N$ in long-term croprotations after adopting no-tillage management: comparison ofsoil sampling strategies. In: Malhi SS, Lemke R, Wang ZH, Chhabra BS (2006). Tillage, nitrogen and crop residue effects on crop yield, nutrient uptake, soil quality, and greenhouse gas emissions. Soil and Tillage Research 90:171183.

Canarche A, Florea N, Râşnoveanu A, Latiş L (1987). Soil Survey Methodology Elaboration, $3^{\text {rd }}$ Part, Pedological Indicators, Bucharest $106 \mathrm{p}$.
Carter MR (1994). Strategies to overcome impediments to adoption of conservationtillage. In: Carter MR (Ed.), Conservation Tillage in Temperate Agroecosystems. In: Fuentes M, Govaerts B, De Leónc F, Hidalgo C, Dendooven L, Sayre KD, Etchevers J (2009). Fourteen years of applying zero and conventional tillage, crop rotation andresidue management systems and its effect on physical and chemicalsoil quality. European Journal of Agronomy 30:228237.

CAST (1992). Preparing U.S. Agriculture for Global Climate Change. Task Force Report No. 119. Council for Agricultural Science and Technology. In: Johnson JM-F, Franzluebbers AJ, Weyers SL, Reicosky DC (2007). Agricultural opportunities to mitigate greenhouse gas emissions. Environmental Pollution 150:107-124.

Cherubini F, Ulgiati $S$ (2010). Crop residues as raw materials for biorefinery systems - A LCA case study. Applied Energy 87:47-57.

Commission Regulation (EC) No 1122/2009 of 30 November 2009 laying down detailed rules for the implementation of Council Regulation (EC) No 73/2009 as regards crosscompliance, modulation and the integrated administration and control system, under the direct support schemes for farmers provided for that Regulation, as well as for the implementation of Council Regulation (EC) No 1234/2007 as regards cross-compliance under the support scheme provided for the wine sector.

Council Regulation (EC) No 73/2009 of 19 January 2009 establishing common rules for direct support schemes for farmers under the common agricultural policy and establishing certain support schemes for farmers, amending Regulations (EC) No 1290/2005, (EC) No 247/2006, (EC) No 378/2007 and repealing Regulation (EC) No 1782/2003.

Crutzen PJ, Heidt LE, Krasnec JP, Pollock WH, Seiler W (1979). Biomass burning as a source of the atmospheric gases $\mathrm{CO}, \mathrm{H} 2$, $\mathrm{NwO}, \mathrm{NO}, \mathrm{CH} 3 \mathrm{C} 1$ and COS. In: Vadrevu KP, Giglio L, Justice C (2013). Satellite based analysis of fire-carbon monoxide relationships from forest and agricultural residue burning (2003-2011). Atmospheric Environment 64:179191.

Diekow J, Mielniczuk J, Knicker H, Bayer C, Dick DP, KögelKnabner I (2005). Soil C and N stocks as affected by cropping systems and nitrogen fertilisation in a southern Brazil Acrisolmanaged under no-tillage for 17 years. Soil and Tillage Research 81:87-95.

Dumitru M, Dumitru E, Gament E, Cârstea S, Ciobanu C, Cojocaru G, Plaxienco D, Manea A, Calciu I, Motelică DM, Enache R, Radnea C, Vrânceanu N, Mashali AM (2000). Soil Quality Monitoring in Romania. GNP Publishing, Bucharest, 53p.

Estrellan CR, Iino F (2010). Toxic emissions from open burning. Chemosphere 80:193-207.

European Commission (EC). Commission decision of 30.6.2009 establishing a template for National Renewable Energy Action 
261

Plans under Directive 2009/28/EC.

FAO (2013). FAOSTAT. Burning Crop Residues metadata, http://faostat.fao.org/site/738/

Franzluebbers AJ (2002). Soil organic matter stratification ratio as an indicator of soil quality. Soil and Tillage Research 66:95106.

Fuentes M, Govaerts B, De Leónc F, Hidalgo C, Dendooven L, Sayre KD, Etchevers J (2009). Fourteen years of applying zero and conventional tillage, crop rotation and residue management systems and its effect on physical and chemical soil quality. European Journal of Agronomy 30:228-237.

Gonçalves C, Evtyugina M, Alves C, Monteiro C, Pio C, Tomé M (2011). Organic particulate emissions from field burning of garden and agriculture residues. Atmospheric Research 101:666-680.

Granged AJP, Zavala LM, Jordán A, Bárcenas-Moreno G (2011). Post-fire evolution of soil properties and vegetation cover in a Mediterranean heathland after experimental burning: A 3year study. Geoderma 164:85-94.

Haider MZ (2013). Determinants of rice residue burning in the field. Journal of Environmental Management 128:15-21.

Hartemink AE (2008). Sugarcane for bioethanol - soil and environmental issues. In: Thorburn PJ, Meier EA, Collins K, Robertson FA (2012). Changes in soil carbon sequestration, fractionation and soil fertility in response to sugarcane residue retention are site-specific. Soil and Tillage Research 120:99111.

IPCC (2007). Assessment Report 4. In: Cooper JM, Butler G, Leifert C (2011). Life cycle analysis of greenhouse gas emissions from organic and conventional food production systems, with and without bio-energy options. NJAS Wageningen Journal of Life Sciences 58:185-192.

Johnson JM-F, Franzluebbers AJ, Weyers SL, Reicosky DC (2007). Agricultural opportunities to mitigate greenhouse gas emissions. Environmental Pollution 150:107-124.

Karlen DL, Ditzler C, Andrews SS (2003). Soil quality: why and how? In: Fuentes M, Govaerts B, De Leónc F, Hidalgo C, Dendooven L, Sayre, KD, Etchevers J (2009). Fourteen years of applying zero and conventional tillage, crop rotation andresidue management systems and its effect on physical and chemicalsoil quality. European Journal of Agronomy 30:228237.

Kludze H, Deen B, Weersink A, Van Acker R, Janovicek K, De Laporte A, McDonald I (2013). Estimating sustainable crop residue removal rates and costs based on soil organic matter dynamics and rotational complexity. Biomass and Bioenergy 56:607-618.

Kutcher HR, Malhi SS (2010). Residue burning and tillage effects on diseases and yield of barley (Hordeum vulgare) and canola (Brassica napus). Soil \& Tillage Research 109:153-160.

Lal R (1995). The role of residues management in sustainable agricultural systems. In: Redy DD, Rao AS, Singh M (2001). Crop residue addition effects on myriad forms and sorbtion of phosphorus in a Vertisol. Bioresource Technology 80:92-99.

Lal R (2007). Carbon management in agricultural soils. Mitigation and Adaptation Strategies for Global Change. In: Johnson JM-F, Franzluebbers AJ, Weyers SL, Reicosky DC (2007). Agricultural opportunities to mitigate greenhouse gas emissions. Environmental Pollution 150:107-124.

Lal MM 2008. An overview to agricultural waste burning. Indian Journal of Air Pollution Control 8(1):48-50.

Li LJ, Han X-Z, You M-Y, Yuan Y-R, Ding X-L, Qiao Y-F (2013). Carbon and nitrogen mineralization patterns of two contrasting crop residues in a Mollisol: Effects of residue type and placement in soils. European Journal of Soil Biology 54:16.

Liu H, Jiang GM, Zhuang HY, Wang KJ (2008). Distribution, utilization structure and potential of biomass resources in rural China: With special references of crop residues. Renewable and Sustainable Energy Reviews 12:1402-1418.

Malhi SS, Lemke R, Wang ZH, Chhabra BS (2006). Tillage, nitrogen and crop residue effects on crop yield, nutrient uptake, soil quality and greenhouse gas emissions. Soil and Tillage Research 90:171-183.

Malhi SS, Lemke R (2007). Tillage, crop residue and Nitrogen effects on crop yield, nutrient uptake, soil quality and nitrous gas emissions in a second 4-yr rotation cycle. Soil and Tillage Research 96:269-283.

Ministry of Agriculture and Rural Development, Romanian Agency for Payements and Interventions in Agriculture (2012) - Guide for farmers regarding the compulsory crosscompliance, $2^{\text {nd }}$ Version.

Monforti F, Bódis K, Scarlat N, Dallemand J-F (2013). The possible contribution of agricultural crop residues to renewable energy targets in Europe: A spatially explicit study. Renewable and Sustainable Energy Reviews 19:666-677.

Navarro-Noya YE, Gómez-Acata S, Montoya-Ciriaco N, RojasValdez A, Suárez-Arriaga MC, Valenzuela-Encinas C, Jiménez-Bueno N, Verhulst N, Govaerts B, Dendooven L (2013). Relative impacts of tillage, residue management and crop-rotation on soil bacterial communities in a semi-arid agroecosystem. Soil Biology and Biochemistry 65:86-95.

Nguyen TLT, Hermansen JE, Mogensen L (2013). Environmental performance of crop residues as an energy source for electricity production: The case of wheat straw in Denmark. Applied Energy 104:633-641.

NIS, 2013. Annual yearbook of the Romanian National Institut of Statistics for the period 1991-2009.

Pintilie C, Romoşan Şt, Pop L, Timariu Gh, Sebök P, Guş M (1985). Agrotehnică. Ediţia a doua. Editura Didactică şi Pedagogică, Bucureşti.

Rayment GE (2003). Water quality in sugar catchment of Queensland. In: Thorburn PJ, Meier EA, Collins K, Robertson FA (2012). Changes in soil carbon sequestration, fractionation and soil fertility in response to sugarcane residue retention are site-specific. Soil and Tillage Research 120:99111. 
Redy DD, Rao AS, Singh M (2001). Crop residue addition effects on myriad forms and sorbtion of phosphorus in a Vertisol. Bioresource Technology 80:92-99.

Sahai S, Sharma C, Singh DP, Dixit CK, Singh N, Sharma P, Singh K, Bhatt S, Ghude S, Gupta V, Gupta RK, Tiwari MK, Garg SC, Mitra AP, Gupta PK (2007). A study for development of emission factors for trace gases and carbonaceous particulate species from in situ burning of wheat straw in agricultural fields in India. Atmospheric Environment 41:9173-9186.

Singh G, Jalota SK, Singh Y (2007). Manuring and residue management effects on physical properties of a soil under the rice-wheat system in Punjab, India. Soil and Tillage Research 94:229-238.

Soon YK, Lupwayi NZ (2012). Straw management in a cold semiarid region: Impact on soil quality and cropproductivity. Field Crops Research 139:39-46.

Sparrow SD, Lewis CE, Knight CW (2006). Soil quality response to tillage and crop residue removal under subarctic conditions. Soil and Tillage Research 91:15-21.

Streets DG, Yarber KF, Woo J-H, Carmichael GR (2003). Biomass burning in Asia: annual and seasonal estimates and atmospheric emissions. In: Gadde B, Bonnet S, Menke C, Garivait $S$ (2009). Air pollutant emissions from rice straw open field burning in India, Thailand and the Philippines. Environmental Pollution 157:1554-1558.

Szabó M, Jaeger-Waldau A, Monforti F, Scarlat N, Bloem J, QuicheronM, Huld T, Ossenbrink H (2011). Technical assessment of the Renewable Action Plans. Eur 24926 EN, ISBN 978-92-79-21049-5.

Thorburn PJ, Meier EA, Collins K, Robertson FA (2012). Changes in soil carbon sequestration, fractionation and soil fertility in response to sugarcane residue retention are sitespecific. Soil and Tillage Research 120:99-111.
Vadrevu KP, Giglio L, Justice C (2013). Satellite based analysis of fire-carbon monoxide relationships from forest and agricultural residue burning (2003-2011). Atmospheric Environment 64:179-191.

Verhulst N, Govaert B, Nelissen V, Sayre KD, Crossa J, Raes D, Deckers J (2011). The effect of tillage, crop rotation and residue management on maize and wheat growth and development evaluated with an optical sensor. Field Crops Research 120:58-67.

Viana, M, López JM, Querola X, Alastueya A, García-Gaciob D, Blanco-Herasb G, López -Mahía P, Piñeiro-Iglesiasc M, Sanz MJ, Sanz F, Chie X, Maenhaute W (2008). Tracers and impact of open burning of rice straw residues on PM in Eastern Spain. Atmospheric Environment 42:1941-1957.

Viana M, Reche C, Amato F, Alastuey A, Querol X, Moreno T, Lucarelli F, Nava S, Calzolai G, Chiari M, Rico M (2013). Evidence of biomass burning aerosols in the Barcelona urban environment during winter time. Atmospheric Environment 72:81-88.

Zhang B, Peng X-H (2006). Organic matter Enrichment and Aggregate Stabilization in a Severely Degraded Ultisol After Reforestation. Pedosphere 16(6):699-706.

Zhang H, Ye X, Cheng T, Chen J, Yang X, Wang L, Zhang R (2008). A laboratory study of agricultural crop residue combustion in China: Emission factors and emission inventory. Atmospheric Environment 42:8432-8441.

Zhang Q, Huang J, Yu G (2008). Polychlorinated dibenzo-pdioxins and dibenzofurans emissions from open burning of crop residues in China between 1997 and 2004 Environmental Pollution 151:39-46.

Yao S, Qin J, Peng X, Zhang B (2009). The effects of vegetation on restoration of physical stability of a severely degraded soil in China. Ecological Engineering 35(5):723-734. 